Original Paper http://ajol.info/index.php/ijbcs http://indexmedicus.afro.who.int

\title{
Effects of seed provenance and growth media on the growth performance of Vitellaria paradoxa C.F. Gaertn.
}

\author{
Adeboyin Funmi ADEROUNMU ${ }^{1 *}$, Francoline Jong NKEMNKENG ${ }^{2}$ and \\ Grace MENDI ANJAH ${ }^{2}$ \\ ${ }^{1}$ Federal College of Forestry, Ibadan, Forestry Research Institute of Nigeria. \\ ${ }^{2}$ University of Dschang, Department of Plant Biology, Cameroon. \\ *Corresponding author; E-mail: afaderounmu@gmail.com; Tel. (+234) 8038076422
}

\begin{abstract}
This work investigated the effects of seed provenance and growth media on the growth performance of Vitellaria paradoxa C.F. Gaertn. Seeds were extracted from fresh fruits collected from Eruwa, Saki and NewBussa and sown into six media in black polythene pots: top soil + sawdust (1:1); river sand + top soil (1:1); river sand + sawdust (1:1); top soil only; sawdust only and river sand. The experiment was 3 x 6 factorial laid in a Completely Randomized Design. Germination, seedling height, collar diameter, number of leaves and leaf area were evaluated. Data collected were subjected to Analysis of Variance (ANOVA) at $\mathrm{p}<0.05$ ). Seeds from NewBussa sown on river sand + top soil (1:1) had the highest germination percentage (92\%) while the seeds from Saki sown on top soil only had the least of $74.7 \%$. River sand + top soil medium had the longest seedling growth with $5.41 \mathrm{~cm}$; also rated second in collar diameter $(4.07 \mathrm{~mm})$ and leaf area index $\left(47.95 \mathrm{~cm}^{2}\right)$. Thus, top soil based medium, especially river sand + top soil is recommended for good growth performance of this species collected from any of the three provenances.
\end{abstract}

(C) 2020 International Formulae Group. All rights reserved.

Keywords: Pseudo-radicle, germination, seed source, seedling vigour, traits.

\section{INTRODUCTION}

Plantations of tree species are commonly established with seedlings grown in the nursery. This ensures economy of seed and permits intensive management. However, the quality of seedlings raised is significantly influenced by growth media as well as seed source. Akintoye et al. (2013) asserted that the quality of container-grown ornamental plants is in broad terms, dependent on the physical and chemical composition of the medium, the growing environment and plant management such as watering, pests and disease control. DresbØll (2004) reported that the physical composition of the growing medium can have a profound effect on the supply of water and air to the growing plant. These can as well affect anchorage, nutrient and water holding capacity of the medium. In addition, seed sources represent the best available genetic material for 
planting as exhibited by the parental material (Mbora et al., 2009). Seed source testing of native species is necessary to screen the available variety for higher productivity and future breeding work. Selection of the best seed source of a desired species for a given site or region is necessary to achieve maximum productivity in plantation forestry (Takuathung et al., 2012).

Several authors have examined the importance of these factors on seed germination and early seedling development. Baiyeri (2002) observed significant effects of five growth media formulated from top soil, poultry manure and river sand on seedling emergence and early growth of cashew (Anarcadium occidentalis) and African breadfruit (Treculia africana) seedlings.

In addition, Nzekwe et al. (2013) in an investigation on the effect of six different potting media in raising Irvingia wombulu rootstock budded less than one year of growth. Correlation matrices of media $\mathrm{N}_{2}$ and growth correlators with seedlings girth showed that the propensity for seedling girth increment strongly depend on the nutrient status of the growth media. Furthermore, Aigbe et al. (2016) in their investigation found out that seed sources with higher longitude tend to perform better in terms of germination and produced higher quality seedlings. This may be due to climatic and geographic influences or, more importantly, even genetic differences. Source variation tests are necessary to screen the naturally available genetic variation to select the best planting material for higher productivity (Bhat and Chauhan, 2002) and select suitable genotypes for future breeding programmes (Mamo et al., 2006).

In order to improve the quality of seedling of the species and make it feasible for plantation establishment, this study was undertaken to re-evaluate nursery media and seed source for seedlings produced thereof.

\section{MATERIALS AND METHODS \\ Study area}

This experiment was carried out between March and December, 2018 at the West African Hardwood Improvement Project (WAHIP) nursery of the Forestry Research Institute of Nigeria (FRIN), Ibadan, Nigeria. FRIN is located on the longitude $07^{\circ} 23^{\prime} 18^{\prime \prime} \mathrm{N}$ to $07^{\circ} 23^{\prime} 43^{\prime \prime} \mathrm{N}$ and latitude $03^{\circ} 51^{\prime} 20^{\prime \prime} \mathrm{E}$ to $03^{\circ} 51^{\prime} 43^{\prime \prime} \mathrm{E}$. The climate of the study area is the West African monsoon with dry and wet seasons. The dry season is usually from November through March and is characterized by dry cold wind of harmattan. The wet season usually starts from April to October with occasional strong winds and thunderstorms. Mean annual rainfall is about $1548.9 \mathrm{~mm}$, falling within approximately 90 days. The mean maximum temperature is $31.9{ }^{\circ} \mathrm{C}$, minimum $24.2^{\circ} \mathrm{C}$ while the mean daily relative humidity is about $71.9 \%$ (FRIN 2018).

\section{Seed collection, germination and early growth study}

Freshly collected seeds of $V$. paradoxa from each of the three sources Eruwa, Saki and New-Bussa provenances (Table 1) were divided into six groups of 60 seeds each and sown into black polythene pots $(16 \times 14 \times 12$ $\mathrm{cm}^{3}$ ) separately filled with six media, viz: top soil and sawdust (1:1); river sand and top soil (1:1); river sand and sawdust (1:1); top soil only; sawdust only and river sand only (control). The seeds were lightly covered with the media after sowing and watered daily. The light seed coverage was for easy and safe removal for the examination of pseudo-radicle protrusion and initiation which is taken as germination of the species. These were daily watered and monitored until epicotyls emerged 
from the growing media when seedling development assessment commenced. The germination and early growth study was a $3 \times 6$ factorial experiment $(3$ seed provenances and 6 growth media) making a total of 18 treatments arranged in completely randomized design (CRD) with three replicates (Table 2).

Germination initiation was observed for two (2) weeks from the day pseudo-radicle protrusion was first noticed. Assessment of growth parameters commenced twelve (12) weeks after planting and was done monthly for six (6) consecutive months. Data was collected for pseudo radicle protrusions through daily counting and recording, while plant height $(\mathrm{cm})$, collar diameter $(\mathrm{mm})$, number of leaves and leaf area $\left(\mathrm{cm}^{2}\right)$ were measured.

\section{Statistical analysis}

Data were analyzed by percentages, analysis of variance (ANOVA) and where significant, least significant difference (LSD) test at $5 \%$ probability level carried out to compare the means.

Table 1: Geographic locations and climatic conditions of the different sources of $V$. paradoxa seeds.

\begin{tabular}{llcc}
\hline Seed Source & $\begin{array}{l}\text { Location (Lat. } \\
\text { and Long) }\end{array}$ & $\begin{array}{l}\text { Altitude Above Sea } \\
\text { Level }(\mathbf{m})\end{array}$ & Rainfall (mm) \\
\hline Eruwa & $7^{0} 32^{\prime} 59^{\prime \prime} \mathrm{N}$, & 252 & 1200 \\
& $3^{0} 25^{\prime} 59^{\prime \prime} \mathrm{E}$ & & 1258 \\
Saki & $8^{0} 40^{\prime} 03^{\prime \prime} \mathrm{N}$, & 472 & 1100 \\
& $3^{0} 23^{\prime} 38^{\prime \prime} \mathrm{E}$ & & \\
New Bussa & $9^{0} 53^{\prime} 58^{\prime \prime} \mathrm{N}$, & 170 & \\
& $4^{0} 30^{\prime} 39^{\prime} \mathrm{E}$. & & \\
\hline
\end{tabular}

Table 2: Treatments combinations (18 treatments).

\begin{tabular}{|c|c|c|c|c|}
\hline & \multicolumn{4}{|c|}{ Seed source } \\
\hline & & So & S1 & $\mathbf{S 2}$ \\
\hline & Mo & SoMo & S1Mo & S2Mo \\
\hline & M1 & SoM1 & S1M1 & S2M1 \\
\hline \multirow[t]{4}{*}{ Growth media } & M2 & SoM2 & $\mathrm{S} 1 \mathrm{M} 2$ & S2M2 \\
\hline & M3 & SoM3 & S1M3 & S2M3 \\
\hline & M4 & SoM4 & S1M4 & S2M4 \\
\hline & M5 & SoM5 & S1M5 & S2M5 \\
\hline
\end{tabular}

Note: S0- Eruwa, S1- Saki and S2- New-Bussa;

Mo: Top soil and sawdust (1:1); M1: River sand and top soil (1:1); M2: Top soil only; M3: River sand and sawdust (1:1); M4: Sawdust only; M5: River sand only (control). 


\section{RESULTS \\ Germination percentage}

Germination in $V$. paradoxa varied with sources and growth media ranging between 74.7 and $92.0 \%$. The highest mean germination was recorded for the seeds collected from NewBussa sown in river sand + top soil medium with $92.0 \%$. This was followed by seeds from Eruwa sown in top soil + sawdust medium (90.7\%) while seeds from Saki which were sown on top soil had the least of $74.7 \%$. Considering the cumulative germination from media alone, the highest mean cumulative germination was recorded on top soil + sawdust medium with $87.1 \%$, followed by river sand + top soil medium $(90.7 \%)$ while top soil had the least of $79.6 \%$. Considering the three sources, the highest mean cumulative germination was recorded in Saki with $81.9 \%$, followed by Eruwa $(80.6 \%)$ while New-Bussa had the least of $76.5 \%$ (Table 3 ).

\section{Seedling height $(\mathbf{c m})$}

Growth media, seed sources and their interaction had significant influence $(\mathrm{p}<0.05)$ on the growth of $V$. paradoxa seedlings (Tables 4, 8 and 9). The height of the seedlings raised on various media ranged between $4.67 \mathrm{~cm}$ and $5.41 \mathrm{~cm}$. Seedlings on river sand + top soil exhibited the best performance with mean height growth of $5.41 \mathrm{~cm}$ and was followed by $5.18 \mathrm{~cm}$ from seedlings on top soil + sawdust medium. The least was however recorded in those raised on river sand with $4.67 \mathrm{~cm}$. The LSD test showed that the means were different from one another (Table 8). Although, river sand, sawdust and, mixture of river sand + sawdust media were not different from one another. Top soil + sawdust and river sand + top soil was also not different but differed from the top soil medium $(0.40 \mathrm{~cm})$.

The seedlings from Saki provenance had the highest mean height of $5.42 \mathrm{~cm}$ followed by those from Eruwa source with 4.76 $\mathrm{cm}$ while New-Bussa had the least mean height growth for the species. However, the mean height growth from Eruwa and New-Bussa were not significantly different from each other but differed from that of Saki (0.28).

Interaction of growth media and seed sources was significant and varied with mean height growth ranging from $4.37 \mathrm{~cm}$ to $6.66 \mathrm{~cm}$ (Table 9). Seedlings from Saki raised on top soil + sawdust had the best performance with $6.66 \mathrm{~cm}$ height growth. Saki seedlings raised on top soil + sawdust ranked second $(5.87 \mathrm{~cm})$ while seedlings from New-Bussa on river sand and sawdust media had the least seedling height $(4.37 \mathrm{~cm})$. LSD showed significant differences among the means with different letters (Tables 4 and 9).

\section{Collar diameter (mm)}

The stem diameter growth of the seedlings was significantly $(\mathrm{p}<0.05)$ influenced by the media on which they were raised while seed source and interaction had no significant effect (Tables 5 and 8). Seedlings had diameter growth between $3.30 \mathrm{~mm}$ and $4.65 \mathrm{~mm}$. Seedlings on river sand + sawdust medium had the highest mean stem diameter of $4.65 \mathrm{~mm}$. Seedlings on river sand + top soil medium produced $4.07 \mathrm{~mm}$ mean stem diameter while river sand only produced the least of $3.30 \mathrm{~mm}$. There were differences in the mean diameter growth of seedlings from all the growth media although, top soil + sawdust and, river sand + top soil media did not produce significantly different mean stem diameters.

\section{Number of leaves}

The number of leaves produced by the seedlings were significantly $(\mathrm{p}<0.05)$ affected by growth media and seed source (Tables 6 and 8). However, their interaction had no effect on the seedling leaf production. The number of leaves produced by the seedlings varied between 2.69 and 3.43. The highest mean leaf production was observed on the seedlings raised on the top soil + sawdust medium (3.43). This was followed by those raised on the top soil medium with 3.07 while seedlings raised on river sand had the least (2.70). There were differences in the mean leaf production of the 
species (LSD 0.38). Seedlings from the three sources had leaf production varying from 2.63 to 3.46 with the highest number produced from New-Bussa seedlings while Eruwa seedlings had the least. LSD showed that the mean leaf production from Eruwa and Saki were not different from each other but differed from that of New-Bussa (Table 8).

\section{Leaf area $\left(\mathrm{cm}^{2}\right)$}

Growth media and seed source had significant effect $(\mathrm{p}<0.05)$ on the leaf area of the seedlings while their interaction had none (Tables 7 and 8). The leaf areas produced were between $46.22 \mathrm{~cm}^{2}$ and $48.40 \mathrm{~cm}^{2}$. The highest mean leaf area was recorded for seedlings on the top soil + sawdust medium $\left(48.40 \mathrm{~cm}^{2}\right)$ followed by the seedlings on river sand + top soil and river sand + sawdust media with 47.9 $\mathrm{cm}^{2}$ each. These were followed by seedlings on top soil $\left(47.42 \mathrm{~cm}^{2}\right)$ while those on river sand had the least mean leaf area of $46.22 \mathrm{~cm}^{2}$. LSD showed that the means were significantly different from one another although, means for top soil + sawdust and river sand + top soil were not different. The seedlings from the three seed sources had $52.22 \mathrm{~cm}^{2}, 46.32 \mathrm{~cm}^{2}$ and $43.82 \mathrm{~cm}^{2}$ for Eruwa, New-Bussa and Saki respectively. LSD showed that there were significant differences in the mean leaf areas of the seedlings from the three sources (Table 8).

Table 3: Mean effects of varying growth media on percentage germination of seeds of $V$. paradoxa collected from Eruwa, New-Bussa and Saki.

\begin{tabular}{lcccc}
\hline \multirow{2}{*}{ Growth media } & \multicolumn{5}{c}{ Source/ mean germination (\%) Cum. growth media } \\
\cline { 2 - 5 } & Eruwa & New-Bussa & Saki & \% germination \\
\hline $\mathrm{T}_{1}$ - Top soil + Sawdust & 90.7 & 82.6 & 88.0 & $\mathbf{8 7 . 1}$ \\
$\mathrm{T}_{2}$ - River sand + Top soil & 82.7 & 92.0 & 82.7 & $\mathbf{8 5 . 8}$ \\
$\mathrm{T}_{3}$ - Top soil only & 82.7 & 81.3 & 74.7 & $\mathbf{7 9 . 6}$ \\
$\mathrm{T}_{4}$ - River sand + Sawdust & 88.1 & 82.6 & 80.0 & $\mathbf{8 3 . 6}$ \\
$\mathrm{T}_{5}$ - Sawdust only & 79.9 & 86.6 & 81.3 & $\mathbf{8 2 . 6}$ \\
$\mathrm{T}_{6}$ - River sand only & 81.4 & 87.8 & 81.3 & $\mathbf{8 3 . 5}$ \\
Cum. seed sources & $\mathbf{8 0 . 6}$ & $\mathbf{7 6 . 5}$ & $\mathbf{8 1 . 9}$ & \\
\hline
\end{tabular}

Source: Field Study, 2018.

Table 4: ANOVA for the effect of growth media and seed sources on seedling heights of V. paradoxa.

\begin{tabular}{lllll}
\hline Variables & df & ms & f-value & p-level \\
\hline Height (cm) & & & & \\
Growth media (GM) & 5 & 5.202 & $4.74^{*}$ & $0.000^{*}$ \\
Seed sources (SS) & 2 & 21.271 & $19.37^{*}$ & $0.000^{*}$ \\
GM x SS & 10 & 2.931 & $2.67^{*}$ & $0.004^{*}$ \\
Error & 306 & 1.098 & & \\
\hline
\end{tabular}


Table 5: ANOVA for the effect of growth media and seed sources on stem collar diameter of $V$. paradoxa $(\mathrm{mm})$.

\begin{tabular}{lllll}
\hline Variables & df & ms & f-value & p-level \\
\hline Growth media & 5 & 13.62 & $6.71^{*}$ & $0.000^{*}$ \\
Seed sources & 2 & 3.64 & $1.79 \mathrm{~ns}$ & 1.168 \\
GM x SS & 10 & 1.94 & $0.95 \mathrm{~ns}$ & 0.484 \\
Error & 306 & $2.03^{*}$ & & \\
\hline
\end{tabular}

Table 6: ANOVA for the effect of growth media and seed sources on number of leaves of $V$. paradoxa seedlings.

\begin{tabular}{lllll}
\hline Variables & df & ms & f-value & p-level \\
\hline Growth media & 5 & 4.04 & $3.91^{*}$ & $.0002^{*}$ \\
Seed sources & 2 & 21.17 & $20.48^{*}$ & $0.000^{*}$ \\
GM x SS & 10 & 0.77 & $0.74 \mathrm{~ns}$ & 0.685 \\
Error & 306 & 1.03 & & \\
\hline
\end{tabular}

Table 7: ANOVA for the effect of growth media and seed sources on seedling leaf area of $V$. paradoxa $\left(\mathrm{cm}^{2}\right)$.

\begin{tabular}{lllll}
\hline Variables & df & ms & f-value & p-level \\
\hline Growth media & 5 & 35.68 & $3.01^{*}$ & $0.011^{*}$ \\
Seed sources & 2 & 2007.34 & $169.54^{*}$ & $0.000^{*}$ \\
GM x SS & 10 & 10.94 & $0.92 \mathrm{~ns}$ & 0.511 \\
Error & 306 & 11.84 & & \\
\hline
\end{tabular}

$*$ Significant at $\mathrm{p} \leq 0.05 ; \mathrm{ns}=$ not significant. 
Table 8: Follow up test (LSD) for the mean effect of varying growth media on the seedlings of $V$. paradoxa from three sources.

\begin{tabular}{lllll}
\hline Variables & Height $(\mathbf{c m})$ & Stem diam. $(\mathbf{m m})$ & No. of leaves & Leaf area $\left(\mathbf{c m}^{2}\right)$ \\
\hline Growth media & & & & \\
Top soil + Sawdust (1) & $5.18 \mathrm{bc}$ & $3.81 \mathrm{abc}$ & $2.96 \mathrm{ab}$ & $48.40 \mathrm{c}$ \\
River sand + Top soil (2) & $5.41 \mathrm{c}$ & $4.07 \mathrm{c}$ & $2.91 \mathrm{ab}$ & $47.95 \mathrm{bc}$ \\
Top soil only (3) & $4.86 \mathrm{ab}$ & $3.34 \mathrm{ab}$ & $3.43 \mathrm{c}$ & $47.42 \mathrm{abc}$ \\
River sand + Sawdust (4) & $4.70 \mathrm{a}$ & $4.65 \mathrm{~d}$ & $3.07 \mathrm{bc}$ & $47.95 \mathrm{bc}$ \\
Sawdust only (5) & $4.68 \mathrm{a}$ & $3.84 \mathrm{bc}$ & $2.69 \mathrm{a}$ & $46.81 \mathrm{ab}$ \\
River sand only (6) & $4.67 \mathrm{a}$ & $3.30 \mathrm{a}$ & $2.70 \mathrm{ab}$ & $46.22 \mathrm{a}$ \\
LSD & $\mathbf{0 . 4 0}$ & $\mathbf{0 . 5 4}$ & $\mathbf{0 . 3 8}$ & $\mathbf{1 . 3 0}$ \\
Seed sources & & & & \\
Eruwa & $4.76 \mathrm{a}$ & $\mathrm{ns}$ & $2.63 \mathrm{a}$ & $5.22 \mathrm{c}$ \\
New-Bussa & $4.58 \mathrm{a}$ & $\mathrm{ns}$ & $3.46 \mathrm{~b}$ & $46.32 \mathrm{~b}$ \\
Saki & $5.42 \mathrm{~b}$ & $\mathrm{~ns}$ & $2.79 \mathrm{a}$ & $43.82 \mathrm{a}$ \\
LSD & $\mathbf{0 . 2 8}$ & $\mathbf{0 . 3 8}$ & $\mathbf{0 . 2 7}$ & $\mathbf{0 . 9 2}$ \\
\hline
\end{tabular}

Note: Means with the same alphabets along a column are not significantly different.

Table 9: Follow up test (LSD) for the effect of interaction of varying growth media and seed sources on seedling development of $V$. paradoxa.

\begin{tabular}{ll}
\hline Variables & Height $(\mathbf{c m})$ \\
\hline Growth media x Seed sources & \\
River sand only x New-Bussa & $4.37 \mathrm{a}$ \\
Sawdust only x New-Bussa & $4.37 \mathrm{a}$ \\
River sand + Top soil x New-Bussa & $4.51 \mathrm{ab}$ \\
River sand + Sawdust x Eruwa & $4.56 \mathrm{ab}$ \\
Sawdust only x Eruwa & $4.58 \mathrm{ab}$ \\
Top soil + Sawdust x New-Bussa & $4.58 \mathrm{ab}$ \\
River sand only x Eruwa & $4.58 \mathrm{ab}$ \\
Top soil only x Eruwa & $4.67 \mathrm{abc}$ \\
River sand + Sawdust x Saki & $4.74 \mathrm{abc}$ \\
River sand + Sawdust x New-Bussa & $4.81 \mathrm{abc}$ \\
Top soil only x New-Bussa & $4.82 \mathrm{abc}$ \\
River sand only x Saki & $5.06 \mathrm{bc}$ \\
River sand + Top soil x Eruwa & $5.07 \mathrm{c}$ \\
Top soil + Sawdust x Eruwa & $5.08 \mathrm{c}$ \\
Top soil only x Saki & $5.09 \mathrm{c}$ \\
Sawdust only x Saki & $5.09 \mathrm{c}$ \\
Top soil + Sawdust x Saki & $5.87 \mathrm{~d}$ \\
River sand + Top soil x Saki & $6.66 \mathrm{e}$ \\
LSD & $\mathbf{0 . 5 4}$ \\
\hline
\end{tabular}

Note: Means with the same letters along a column are not significantly different. 


\section{DISCUSSION}

The combination of top soil, river sand and sawdust expectedly constituted differences in media's physical, chemical and biological properties (Six et al., 2000; Carter, 2002). Good seedling emergence could reflect the quality of the soil physical properties (Kushwala et al., 2001; Onemli, 2004). A good blend of soil media with varying physical and chemical properties can create a beneficial growth environment for plants; this is evident in the resultant germination and height growth of seedlings grown in river sand + top soil medium. Thus, effects of growth media on germination and emergence of seedlings were significant with growth media having top soil in their composition forming better media for germination; which is in line with the findings of Adeoluwa et al. (2014) in the growth study of Ficus retusa. In addition, Ehiagbonare and Onyibe (2008) observed that forest topsoil supported better seedlings growth of Albizia lebbeck, Alstonia boonei and Afzelia africana than river sand. Germination percentages were highest for Saki and the most appropriate medium being the topsoil + sawdust combination. The appreciable germination percentage of $V$. paradoxa seeds from the three provenances sown in various media could be attributed to sowing of freshly collected seeds. This is in line with assertion of Aderounmu and Asinwa (2019) that $V$. paradoxa seeds should be sown immediately after collection as substantial percentages of germination would be achieved. Hall et al. (1996) earlier reported that $V$. paradoxa being a recalcitrant species are noticeably short-lived and cannot lose moisture content below 20-30\% without injury.

Regarding emergence, seedling growth is linked to root elongation and nutrient uptake while growth and elongation of roots area function of the type of media, water content, oxygen concentrations and gas exchange
(Fageria et al., 2014). Hence, substrates having higher amounts of these physical properties would give better seedling emergence and growth. Seed germination and seedling emergence result from a sequence of biological events initiated by water imbibitions followed by enzymatic metabolism of stored nutrients (Maroufi, 2011). Similarly, remarkable influence of potting mixture on the growth variables of $V$. paradoxa could be as a result of media having considerable aeration and water holding capacity under favourable environmental factors (Hall et al., 1996).

The results of this study conform to those of Anjah et al. (2015) and Nzekwe et al. (2013) who evaluated the effects of growth media on the germination and seedlings growth of Aframomum melegueta and Milicia excelsa respectively. These results also corroborate with the findings of Ndam et al. (2010) who worked on the domestication of Gnetum africana as well as Kanmegne et al. (2017) who studied the effects of substrates on Xylopia aethiopica. Equally, the findings of Baiyeri (2002) who carried out an investigation on two tropical tree species Anarcadium occidentalis Linn (cashew) and Treculia africana Decne (African breadfruit) grown on five nursery media formulated from top soil, poultry manure and river sand at different ratios also showed some similarities.

In addition, seedlings growth parameters were also significant for the different seed sources provenances. According to Aigbe et al. (2016) seeds emerging from higher latitude tend to perform better in terms of germination and seedlings qualities. The significant effect of seed sources on germination and growth rate found in the study could be associated to the trees' genetic milieu which also determined the seeds quality (Bagchi et al., 1990). The altitude of the seed collection site has effect on the germination 
(Holm 1994) is reflected in the higher germination rate recorded by seeds from Saki than seeds from the other two locations. In addition, climatic factors such as temperature or rainfall prevailing during the fructifcation could be involved in poor or high percentage of germination as opined by Humara et al. (2000) in Eucalyptus nitens. Fandohan et al. (2010) also observed that there is a relationship between the Tamarind seeds' growth and their sources with respect to climatic zones. Thus, the performance of a species depends partly on the site and seed source.

\section{Conclusion}

It was found from the result of this study that seeds of $V$. paradoxa could be collected from any of the provenances within the distribution range of the species most especially for germination and that seedlots to be sown must be freshly collected for optimum germination. Also, irrespective of the provenances, all the sowing media: top soil + sawdust, river + top soil, river + and sawdust, top soil only, sawdust only and river sand only (control) relatively supported the germination of $V$. paradoxa. However, growth media composing of top soil have proven its influence on the germination and growth potentials of the species. It is therefore recommended for optimum germination and vigorous growth of $V$. paradoxa, that top soil + river sand could be used for exhibiting overall better performance than other media in this study.

\section{COMPETING INTERESTS}

The authors declare that they have no competing interests.

\section{AUTHORS' CONTRIBUTIONS}

AFA carried out the field exercise and produced the first draft while GMA and FJN edited and fine-tuned the first manuscript. They both formatted the manuscripts in all the different aspects according to the instructions of the journal.

\section{ACKNOWLEDGEMENTS}

We wish to acknowledge the support of the Forestry Research Institute of Nigeria for the enabling environment to carry out the experiments described in this work. We also appreciate the College of Technology, The University of Bamenda, for the technical materials in editing and preparing the final manuscript for submission.

\section{REFERENCES}

Adeoluwa OO, Akinkunmi OY, Akintoye HA, Shokalu AO. 2014. Rooting, growth and sustainability of yellow Ficus (Ficus retusa 'Nitida') as affected by growth media under nursery conditions. Int. J. Biol. Chem. Sci., 8(5): 2071-2080. DOI: https://dx.doi.org/10.4314/ijbcs.v8i5.13

Aderounmu AF, Asinwa IO. 2019. Effects of seed source, moisture content and duration of storage on the viability of Vitellaria paradoxa C.F. Gaertn. Journal of Advances in Biology \& Biotechnology, 22(1): 1-6.

Aigbe HI, Fredrick C, Omokhua GE. 2016. Effect of seed source on germination and early seedling growth of Heinsia crinita (Afzel.) G. Taylor. Applied Tropical Agriculture, 21(3): 180-185. DOI: https://www.researchgate.net/publication /316065345

Akintoye AH, Adeoluwa OO, Akinkumi OY. 2013. Effects of different growth media on the growth and flowering of beefsteak (Begonia erythrophylla). Journal of Applied Horticulture, 15(1): 57-66. DOI: 10.37855/jah.2013.v15i01.10.

Anjah GM, Fotso E, Tonjock RK, Ndikum VM. 2015. Effects of varying 
temperatures, growth media and sowing methods on the germination of Afragmomum melegueta. Int. Jour. Curr. Microbiology and Applied Sciences, 4(3): 659-665. http://www.ijcmas.com

Bagchi SK, Joshi DN, Rawat DS. 1990. Variation in seed size of Acacia spp. Silvae Genet., 39: 107-110.

Baiyeri KP. 2002. Evaluation of nursery media for seedling emergence and early seedling growth of two tropical tree species. Proceedings of the $20^{\text {th }}$ Annual Conference of Horticultural Society of Nigeria, NIHORT, Ibadan.

DOI:10. 4314/mjar.v4i1.31754.

Bhat GS, Chauhan PS. 2002. Provenance variation in seed and seedling traits of Albizia lebbeck. Benth. Journal of Tree Sciences, 21: 52-57.

Carter MR. 2002. Organic matter and aggregation interactions that maintain soil functions. Soil quality for sustainable management. Agron. J., 94: 38-87. DOI: http://doi.org/10.2134/agronj2002.3800.

DresbØll BD. 2004. Optimization of growing media for organic greenhouse production. PhD Thesis, Department of Horticulture, Danish Institute of Agricultural Sciences, p. 115 .

Ehiagbonare JE, Onyibe HI. 2008. Studies on raising and preparation of planting stock of three indigenous forest timber species in Nigeria. Int. J. Biol. Chem. Sci., 2(4): 573-578.

Fageria NK, Gheyi HR, Carvalho MCS, Moreira A. 2014. Root growth, nitrogen and phosphorous uptake and use efficiency in tropical legumes crops as influenced by phosphorous fertilization. $I$. I. Inovagri., 6(06): 6p. DOI: http//dx.doi.org.10.12702/ii.inovagri.201 4-a606.
Fandohan B, Assogbadjo AE, Kakai RG, Sinsin B. 2010. Variation in seed morphometric traits, germination and early seedling growth performances of Tamarindus indica L. Int. J. Biol. Chem. Sci., 4(4): 1102-1109. DOI: https://dx.doi.org/10.4314/ijbcs.v4i4.630 47

Hall JB, Aebischer DP, Tomlinson HF, OseiAmaning A, Hindle JR. 1996. Vitellaria paradoxa, A Monograph. School of Agricultural and Forest Sciences, University of Bangor, UK. 105 p.

Holm SO. 1994. Reproductive patterns of Betula pendula and B. pubescens coll. along a regional altitudinal gradient in northern Sweden. Ecography, 17: 60-72.

Humara JM, Lopez M, Csares A, Majada J. 2000. Temperature and provenance as two factors affecting Eucalyptus nitens seed germination. Forestry, 73: 87-90.

Kanmegne G, Mbibong DA, Fotso, Omokolo DN. 2017. Effects of substrates, different pretreatment protocols and dehydration on the induction of seeds germination of Xylopia aethiopica (Dunal) A. Rich. Int. J. Biol. Chem. Sci., 11(2): 597-608. DOI: https://dx.doi.org/10.4314/ijbcs.v11i2.6

Kushwala CP, Tripathi SK, Singh KD. 2001. Soil organic matter and water stable aggregates under different tillage and residue conditions in a tropical dry land agro ecosystem. Appl. Soil Ecol., 16: 229-241.

DOI: http://doi.org/10.1016/S09291393(00)001121-9

Mamo N, Mihretu M, Fekadu M, Tigabu M, Teketay D. 2006.Variation in seed and germination characteristics among Juniperus procera populations in Ethiopia. Forest Ecology and Management, 225: 320-327. DOI: http//doi.org/10.1016/j.foreco.2006.01.0 26. 
Maroufi K, Farahani HA, Aghdam AM. 2011. Effect of nano priming on germination in sunflower (Helianthus annuus L.). Adv. Environ. Biol., 5(13): 3747-3750. http://www.aensionline.com/aeb/2011/3.

Mbora A, BarnekovLilles $\varnothing$ JP, Schmidt L, Angaine P, Meso M, Omondi W, Ahenda J, Mutua N A, Orwa C, Jamnadass R. 2009. Tree Seed Source Re-classification Manual. World Agroforestry Centre, Nairobi, Kenya, 34 p.

Ndam N, Nkefor JP, Blackmore P. 2001. Domestication of Gnetum africanum and G. bulchholzianum (Gnetaceae) overexploited wild forest vegetables of the Central African Region. Systematics and Geography of Plants, 71(2): 739-745. DOI:10 2307/366871.

Nzekwe U, Ubani CS, Ajuziogu GC. 2013. Effects of seed pre-treatment and media on seed germination and seedling growth of Iroko, Milicia excelsa (Welw)
CC. Berg moraceae, Syn. Chlorophora excelsa. African Journal of Agricultural Research, 8(18): 2057-2062. DOI: 10.5897/AJAR121981.

Onemli F. 2004.The effects of soil organic matter on seedling emergence in sunflower, Plant Soil Environ., 50(11): 494-499.

Six J, Elliott ET, Paustian K. 2000. Soil structure and soil organic matter II. A. Normalized stability index the effect of mineralogy, Soil Sci. Soc. Am. J., 64: 1042-1049.

www.elsevier.com/locate/soilbio.

Takuathung CN, Pipatwattanakul D, Bhumibhamon S. 2012. Provenance Variation in Seed Morphometric Traits and Growth Performance of Senna siamea(Lam.) Erwin et Barnebyat Lad. Kasetsart Journal of Nat. Science, 46: 394-407. DOI:Ii01.tci-thaijo.org 